\title{
The Implementation Strategy to Reform the Training Modes of Engineering Applied Talents in Local Colleges and Universities
}

\author{
Shao Defu \\ Jiamusi University \\ Heilongjiang, Jiamusi 154007
}

\author{
Ma Xiaojun \\ Jiamusi University \\ Heilongjiang, Jiamusi 154007 \\ mjzx2009phd@163.com
}

\author{
Li Chunjiang* \\ Jiamusi University \\ Heilongjiang, Jiamusi 154007 \\ jmslcj@sohu.com
}

\begin{abstract}
Local universities fall within the category of teaching-research universities for the most part, aimed basically at cultivating "high-quality applied" talents. They emphasize the application of advanced thoughts, ideas, and achievements of school operation to talent cultivation modes and boost students' comprehensive quality through increased practical teaching and by encouraging innovation and co-establishment of bases of production, education \& research to develop engineering students' practical ability and innovation spirit. This paper probes into the paths of reform in the training modes of applied engineering talents in local universities in terms of training programs, curriculum systems, practice-based teaching, training modes, evaluation mechanisms and safeguards to cultivate students' innovation and practical abilities and improve quality of talent training.
\end{abstract}

Keywords - Local college and universities, applied, engineering talents, training modes, reform measures

\section{INTRODUCTION}

Since the beginning of the 21st century, as global economic competition further intensifies, development and employment of higher-education talents has become market-oriented. During the transition from "elite education" to "mass education", when quality and innovation education are desired, reform in quality and mode of higher-education talent development is more of a concern.

Training of engineering applied innovative talents is necessary for the building of the innovation-orientation country, and it also roles as the primary mission for ordinary colleges and universities while education is the key to the cultivation of innovative talents. "What talents to be trained and how to train talents" is the fundamental problem that needs to be solved in the development of socialist education with training mode reform being the core of teaching reform. The training mode reform must be based on the premise of adapting to the local

Supported by 2017 key educational science planning projects of Heilongjiang province: "A Study on the Training Modes of Innovative Ability for "New Engineering" Students in Local College and Universities" and “Teaching Research of Jiamusi University” (2017LGL-007).

*Correspondence Author: Li Chunjiang(1970-), master tutor economic construction and development, grasping the environment and policies of the local social and economic development, and adhering to the educational philosophy of "comprehensive involvement, solid foundation and qualityoriented". Training a large number of high-quality, multi-level applied talents designated to local service industry to assume the responsibility of cultivating applied talents for the regional economic industry chain. According to the characteristics of the training of applied engineering talents in local colleges and universities, the paper explores the paths and methods of the training mode reforming of applied engineering talents, and puts forward the improvement measures for the reform of the training mode of applied engineering talents.

\section{DEEPENING OF REFORM IN TEACHING CONTENT AND CURRICULUM SYSTEMS AND ADJUSTMENT \& UPGRADING OF TALENTS TRAINING PROGRAMS}

In order to match the goal of cultivating high-quality engineering applied talents, it is important to build curriculum and content systems featuring "Three platforms, N module, One extension" which conform to the cultivation of applied talents in modern engineering colleges and universities by deepening reform in teaching content and curriculum systems and adjusting \& upgrading talents training programs. "Three platforms" refers to the teaching platforms for general courses and basic courses in discipline, the practical teaching platform and the like; "N-module", the curriculum module composed of multiple courses in specialty; and "One extension", the teaching system with extracurricular innovation education and quality education as the extension of teaching. Based on the demand standard of socialist talents, general education include courses involving philosophy and social sciences, history and culture, literature and art, and natural sciences, offered as compulsory and elective options in which way, ensure students' basic quality education while taking into account their needs for personal development. The provision of basic knowledge in disciplines on the teaching platform for basic 
courses in disciplines is intended to break disciplinary barriers and achieve the integration of specialized knowledge. The education will lay a foundation for students' specialized studies and meet the demand for comprehensive-involvement and solid-foundation talents. The practical teaching platform includes design and comprehensive experiments, course design, industry practice, graduation field practice and graduation design. In the talent training program, the "module" composed of multiple courses in specialty is mainly designed to develop students' theoretical knowledge and practical ability, and improve their capacities to solve practical engineering problems. The "module" is helpful for the connection between the comprehensive involvement cultivation and increasingly developed social division of labor, and to designate engineering applied talents urgently demanded to the front line areas. At the same time, physical education curriculum reform of integrative in-class \& extra-curricular teaching and of integrating in-class education with extra-curricular exercises can improve students' interest in sports, physical quality, abilities to bear hardships and stand hard work and their unflinching will in order to lay a good foundation for the development of talents.

\section{EMPHASIS OF STUDENTS' SUBJECTIVITY AND ENHANCEMENT OF EDUCATIONAL AND TEACHING INNOVATION}

Educators should use innovative theories and modern educational technical aids, follow the laws of innovation activities and of the formation of students' innovative quality, adopt new teaching modes response to the information age to fully mobilize students' initiatives of learning, and improve teaching outcomes.

\section{A. Innovation of teaching content}

Educators should impart knowledge not only of a specific discipline, but of other related ones to increase multidisciplinary involvement, getting rid of closed-minded and outdated ideas about disciplines. They should arrange comprehensive independent inquiry learning and experiential learning resolving around open-ended questions and encourage students to engage in and copy with real life problems using multi-disciplinary knowledge. In this way, teaching is truly open to students and the future, and integrates with the society rather than being limited to schools.

\section{B. Innovation of teaching methods}

Educators should change traditional teaching modes with "imparting systematic knowledge as the core", while vigorously promoting participatory, heuristic, discussionoriented interactive teaching modes, encourage case teaching, task-driven method, simulation training method, "cold-dishlike” and bilingual teaching, explore research-based teaching and exploration-based learning as well as seminars. The teaching methods should fully mobilize initiatives of teachers and students, and explore students' innovative potentials. Open interactive teaching will guide students to discuss the teaching process, contents, methods and teaching behavior, and to put forward some suggestions as it integrates teachers' leading role with students' initiatives.

\section{Innovation of teaching aids}

The traditional teaching aids of chalks plus blackboards is replaced with the application of information technology like hypermedia technology, streaming media broadcasting technology, virtual reality and the like to build a network teaching classroom response to students' individuality and learning style. Modern educational technical aids are expected to be made full use of to offer brand-new teaching aids.

\section{Innovation of standards and methods of teaching outcomes evaluation}

Standards and methods of teaching outcomes evaluation in various forms and of different levels are built to evaluate students' learning in a comprehensive, holistic, active and flexible way. Overall evaluations of students, should not only assess how much students have mastered the contents of the curriculum, but more importantly, exam their creativity, ability to explore and knowledge analysis and application skills. Those evaluations are subjective and objective, qualitative and quantitative; and they come from teachers, one and others. That not only takes into account of students' foundation, but is improvement-referred, which is indeed helpful to achieve the objective of progress for everyone.

\section{STRENGTHENING THE CONSTRUCTION OF PRACTICAL TEACHING AND EMPHASIZING THE CULTIVATION OF STUDENTS ' PRACTICAL ABILITY}

Centering on the orientation of school operation and the goal of talent training, a practical teaching system is constructed featuring "One main line, two platform, three levels, and four modules ". With the training of students' practical ability and innovation spirit as "One main line", supported by the first and second classrooms, three levels of practical teaching of foundation, application and innovation is constructed and four practical teaching modules of experimental practice, design and thesis, skills and competitions and social practice are formed. Open practical teaching systems which are closely related to but relatively independent from theoretical teaching, taking students as the main part are built. System construction should adapt to the laws of students' development and the process of knowledge accumulation, proceed step by step, and be continuous, reasonable and practical.

\section{A. Strengthening the first classroom practical teaching}

More weight should be put on the development of comprehensive and design experiment projects with the number of courses accounting for more than 85\%. The proportion of independently set experimental courses is increased with engineering courses taking up over $10 \%$ of the total. The internships, curriculum designs and graduation designs for engineering majors should be further guided, carefully organized and managed as required to ensure quality. College students professional skill assessment systems are constructed and basic professional skill assessment for engineering students implemented to boost their consciousness and ability of engineering practice, and it should be made clear that all students must pass the skill assessment. 


\section{B. Construction of the second classroom of practical teaching}

Active efforts should be put into organizing students to take part in the National Challenge Cup, Blue Bridge Cup, electronic design, program design, mathematical modeling, and numerical control and other out-of-school disciplinary and skill contests. Campus competitions are elaborately planned and made set and institutional. With university students scientific \& technological and cultural festival as a carrier, a variety of scientific and cultural activities are held. Innovative experiments are organized and established, scientific \& technological practice plans implemented and "innovation credits" set up. Students are encouraged to participate in scientific \& technological innovation activities and provided with opportunities to participate in teachers' scientific research activities or define their own research projects.

\section{Strengthening the construction of laboratories and practice bases}

Schools should make enough investment in building laboratories and experimental centers and in improving practical teaching conditions of the pilot subjects for improved practical teaching. At the same time, they also should vigorously strengthen cooperation with local, especially various enterprises, select a group of enterprises and institutions which involve the characteristics of specialty as long-term practical teaching bases outside school. The harmonious connection of students' cognition practice, production practice in the training bases and campus practical teaching promotes the formation of the complete training system of engineering applied talents which plays a essential role in the cultivation of applied talents of various specialties.

\section{CONSTRUCTING A TEACHING QUALITY EVALUATION SYSTEM BASED ON THEORY AND PRACTICE}

The evaluation of teaching quality is an important measure to ensure the training quality of applied talents, and it works as a basic link of teaching. The system is constructed from the following two paths, taking into consideration of schools, disciplines and students.

The first is to improve the teaching quality monitoring system. First of all, the organizational system of teaching quality monitoring should be established and three-level monitoring be performed from the school teaching supervision group, the faculty teaching-research office to the class committee. Secondly, all factors involving teaching quality are monitored including classroom teaching, experimental teaching, practice and practical training and graduation design (thesis) and others. Third, the assessment of teaching quality evaluation results and the incentive system of teaching quality performance are implemented so as to prompt all faculties to have quality awareness and improve talent training quality.
The second is to establish the practice and practical training system. First of all, course exams, project examination and professional qualification are all adopted to assess students' specialized knowledge, professionalism and technical ability. Secondly, universities should organize students to participate in innovative and entrepreneurship training projects, and improve their comprehensive quality by engaging them in scientific research experiments, disciplinary contests, entrepreneurship competitions, science \& technology lectures or symposiums, and so on. Third, schools should strengthen students' practical teaching to train their hands-on ability, application ability and professionalism.

\section{CONCLUSION}

By investigating effective and reliable training modes, specialty setting programs, practical teaching systems and innovative \& practical abilities development methods and ways in the cultivation of engineering applied talents in comprehensive universities, advanced thoughts, ideas and achievements of school operation are translated into specific implementation strategies of talent training. A systematic and feasible practical ability training system and the training modes of engineering applied talents with characteristics of local universities are constructed through cooperative school operation and co-establishment of bases of production, education \& research. Promoting the reform and innovation of the training modes of applied talents will effectively mobilize students' initiatives and thus form a sound style learning marked by aggressive attitudes and hard work, improve their comprehensive quality, innovative spirit, practical ability, personal development, providing some suggestions for applied talents training in relevant universities.

\section{REFERENCES}

[1] Xiaojun Ma, Ze Zhang, Hongwei Pan, etc. The Training Modes of Excellent Engineering Talents in Local Universities in the context of Double First-rate University Construction-A Case Study of Jiamusi University [J]. Science and Technology Entrepreneurship Monthly, 2017, 30 (14): 57-59.

[2] Xiaojun Ma, Chunjiang Li, Ze Zhang, etc. Implementation Strategy of Practical Ability Development of Engineering Students [J]. Economist, 2017, (07): 221-222.

[3] Xiaojun Ma, Chunjiang Li, Hongwei Pan, etc. A Study on the Training Modes of Innovative Ability of Engineering Undergraduates in Local Universities [J]. Science and Technology Entrepreneurship Monthly, 2017, 30 (10): 24-26.

[4] Xuejuan Zi, Mao Li. Exploration of the Training Modes of Applied Undergraduate Talents in Local Universities [J]. Tropical Agricultural Engineering, 2017, 41 (01): 90-93.

[5] Zhenfeng Chen. Exploration and Practice of the Training Modes of Applied Innovative Talents [J]. Journal of Higher Education, 2015, (16): 38+41. [2017-09-01]. 